\title{
Deafferentation of Olfactory Bulb in Subjects Dying with COVID-19
}

Cécilia Tremblaya , Thomas G. Beacha , Anthony J. Intorcia ${ }^{a}$, Jessica E. Walkera,

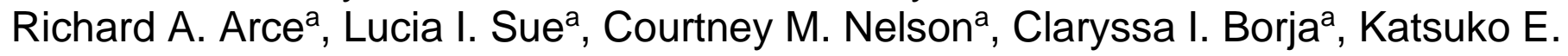
Suszczewicz ${ }^{a}$, Madison P. Cline ${ }^{a}$, Spencer J. Hemmingsena, Sanaria H. Qijia, Marc Desforges $^{\mathrm{b}}$, and Geidy E. Serrano ${ }^{\mathrm{a}}$

aBanner Sun Health Research Institute, Sun City, AZ

${ }^{b}$ Centre Hospitalier Universitaire Sainte-Justine, Laboratory of Virology, Montreal, Canada

Correspondence: Thomas G. Beach, Banner Sun Health Research Institute 10515 West Santa Fe Drive, Sun City, AZ 85351

Telephone: 623-832-5328

Fax: 623-815-2960

Thomas.beach@bannerhealth.com 
medRxiv preprint doi: https://doi.org/10.1101/2021.12.21.21268119; this version posted December 23, 2021. The copyright holder for this

preprint (which was not certified by peer review) is the author/funder, who has granted medRxiv a license to display the preprint in perpetuity.

It is made available under a CC-BY-NC-ND 4.0 International license .

\section{ABSTRACT}

There have been clinical descriptions of diverse neurological effects in COVID-19 disease, involving up to $36 \%$ of patients. It appears likely that most of these are not caused by viral brain invasion but by systemic accompaniments of critical illness such as coagulopathy, deleteriously upregulated immune response, autoimmune mechanisms, hypoxia or multiorgan failure. Anosmia or hyposmia is present in a majority of COVID-19 patients, and there is early and severe involvement of the nasopharyngeal mucosa and olfactory epithelium. Preliminary studies by our group have found massive gene expression changes in olfactory bulb, but the magnitude of these changes are not different between subjects with detectable versus non-detectable olfactory bulb SARS-CoV-2 RNA. As spontaneous discharge of olfactory epithelial afferents dictates intraolfactory bulb neurophysiological activity and connectivity, we hypothesized that olfactory bulb deafferentation during COVID-19 is responsible for a large fraction of our observed olfactory bulb transcriptional changes. As the olfactory marker protein (OMP-1) is a specific marker of olfactory epithelial afferents to the olfactory bulb and is severely depleted in animal model lesions of olfactory epithelium, we quantified OMP-1-

immunoreactivity in the olfactory bulb of subjects dying with or without COVID-19. Additionally, we quantified olfactory bulb tyrosine hydroxylase (TH), which is often also reduced after olfactory epithelium lesions, and SNAP-25, a pan-synaptic marker. COVID-19 cases $(n=18)$ were generally elderly and were not significantly different in age or gender distribution from the non-COVID-19 cases $(n=28)$. Both COVID-19 and nonCOVID-19 cases had a wide range of neuropathological diagnoses. The area occupied by OMP-1 immunoreactivity in COVID-19 cases was significantly less, about $60 \%$ of that in control cases but amongst subjects with COVID-19, there was no significant difference between OBT-SARS-CoV-2-PCR-positive and negative cases. There were no significant group differences for TH or SNAP-25, supporting a selective effect for OMP-1. We suggest that olfactory dysfunction, and some of the COVID-19-associated transcriptional changes that we have reported for the olfactory bulb and amygdala, may be due to olfactory bulb deafferentation and subsequent transsynaptic effects. Additionally, animal models of olfactory bulb deafferentation or bulbectomy indicate a possibility for widespread changes in interconnected brain regions, providing a possible substrate for diverse post-acute COVID-19 neurological sequelae.

Key words. olfactory marker protein; gene expression; SARS-CoV-2; transsynaptic; virus; CNS; Alzheimer disease; neurodegenerative disease 
medRxiv preprint doi: https://doi.org/10.1101/2021.12.21.21268119; this version posted December 23, 2021. The copyright holder for this

preprint (which was not certified by peer review) is the author/funder, who has granted medRxiv a license to display the preprint in perpetuity.

It is made available under a CC-BY-NC-ND 4.0 International license .

\section{INTRODUCTION}

The coronavirus SARS-CoV-2 is the cause of pandemic severe respiratory disease, termed COVID-19, but there have additionally been clinical descriptions of diverse neurological effects, involving up to $36 \%$ of patients 1-10. What remains unclear is whether these are caused by viral brain invasion or by systemic accompaniments of critical illness such as coagulopathy, deleteriously upregulated immune response, autoimmune mechanisms, hypoxia or multiorgan failure ${ }^{11}$.

More than 20 published studies ${ }^{11-31}$ have utilized RT-PCR methods to determine the presence of SARSCoV-2 genomic fragments in postmortem brain, and although results have been variable, the most likely conclusion is that SARS-CoV-2 brain invasion occurs in only a smaller fraction of subjects, viral copy numbers are low, and proof of in situ viral CNS replication or protein synthesis is lacking ${ }^{13,31-35}$.

Anosmia or hyposmia is present in many COVID-19 patients ${ }^{36-38}$ and clinical, autopsy and animal model evidence has pointed to early and severe involvement of the nasopharyngeal mucosa and olfactory epithelium $27,31,36,39-45$. The olfactory epithelium includes olfactory sensory neurons that project directly through the perforated cribriform plate to the intracranial olfactory bulb, making this pathway a major candidate for brain entry. Of studies localizing SARS-CoV-2 RNA in multiple brain regions of deceased COVID-19 subjects, olfactory bulb has been found to be the single most-involved area ${ }^{31,46}$. Preliminary studies by our group have found massive gene expression changes in olfactory bulb ${ }^{47}$, with lesser but still marked changes in the amygdala, one of its main projection targets. The magnitude of these changes, however, are not different between subjects with detectable versus non-detectable olfactory bulb SARS-CoV-2 RNA. As spontaneous discharge of olfactory epithelial afferents dictates intra-olfactory bulb neurophysiological activity and connectivity $^{48-50}$, we hypothesized that deafferentation during COVID-19 is responsible for the majority of our observed olfactory bulb transcriptional changes. As the olfactory marker protein (OMP-1) is a specific marker of olfactory epithelial afferents to the olfactory bulb ${ }^{51-53}$ and is severely depleted in animal model lesions of olfactory epithelium ${ }^{48,54-57}$, we quantified OMP-1-immunoreactivity in the olfactory bulb of subjects dying with or without COVID-19. Additionally, we quantified olfactory bulb tyrosine hydroxylase (TH) ${ }^{54,55,58}$, which is often also reduced after olfactory epithelium lesions, and SNAP-25, a pan-synaptic marker. 


\section{MATERIALS AND METHODS}

\section{Human Subjects and Characterization}

The COVID-19 subjects were derived from Banner Sun Health Research Institute (BSHRI) in Sun City, Arizona $(n=18)$. Ethical approval for autopsy and subsequent research was obtained for all subjects through Institutional Review Board-approved protocols and informed consent documents (Western IRB, Puyallup, WA; protocols 1132516 and 20201852). Clinical and neuropathological results for some of the COVID-19 cases are described in our prior publications ${ }^{46,47}$ and the complete set of cases used in the present study is summarized in Table 1. All COVID-19 subjects had positive clinical diagnostic test results for SARS-CoV-2 and all were considered to have died acutely or subacutely in 2020 or early 2021 as a result of COVID-19. An additional 28 cases were chosen from 2018, 2019 and 2020 non-COVID-19 BSHRI autopsies, including 13 cases with autopsy-proven non-COVID-19 pneumonia and 15 cases without autopsy evidence of pneumonia. NonCOVID-19 status was determined by autopsy occurrence prior to the COVID-19 US arrival (2018 and 2019 autopsies) or, for 2020 and 2021 cases, by a negative postmortem nasopharyngeal RT-PCR test conducted in a CLIA-approved laboratory.

Published diagnostic clinicopathological consensus criteria for age-related and neurodegenerative brain disease ${ }^{59-71}$ were used when applicable, incorporating research clinical assessment results as well as pertinent private medical history. The histological sampling and staining incorporated the protocols recommended by the National Institute on Aging and Alzheimer's Association (NIA-AA) ${ }^{69-71}$.

Immunohistochemical staining for OMP-1, TH and SNAP-25 was done with commercially obtained antibodies (OMP-1 Novus Biologicals NB110-74751; TH Sigma Aldrich T2928; SNAP-25 Sigma-Aldrich S9684) on formalin-fixed, paraffin-embedded sections of olfactory bulb. Epitope exposure methods used included 20 minutes in boiling $0.1 \mathrm{M}$ sodium citrate for OMP-1 and TH, and 20 minutes in $80 \%$ formic acid for SNAP-25. Primary antibody concentrations used were 1;2,000 for OMP-1, 1:3,000 for TH and 1:5,000 for SNAP-25. Control sections omitted the primary antibodies. Four images per case were captured from slides stained with each antibody. The final magnifications used were 200x for OMP-1 and 400x for TH and SNAP25. Image capture and analyses were done while blinded to subject clinical or autopsy information. 
medRxiv preprint doi: https://doi.org/10.1101/2021.12.21.21268119; this version posted December 23, 2021. The copyright holder for this

preprint (which was not certified by peer review) is the author/funder, who has granted medRxiv a license to display the preprint in perpetuity.

It is made available under a CC-BY-NC-ND 4.0 International license .

The area occupied by stained tissue elements within the olfactory bulb nerve fiber layer and adjacent glomerular layer was determined with digital image analysis (Image $\mathrm{J}$ software with image processing and analysis in Java: https://imagej.nih.gov/ij/). The means of the areas occupied by staining in the 4 images were used for statistical analyses, performed using SPSS software (IBM SPSS Statistics 23.0). Methods included unpaired, two-way t-tests for continuous variables, as well as analysis of variance with post-hoc Bonferronicorrected pairwise significance testing. Fisher Exact tests were used to test for proportional differences and linear regression for relationships between continuous variables. The probability level was set at $p<0.05$.

\section{RESULTS}

Table 1 shows basic data for the cases studied. COVID-19 cases did not significantly differ in age from the non-COVID-19 cases (82.3, SD 8.9 vs 86.2, SD 9.2, respectively). Males made up 11/18 and 18/28 of the COVID-19 and non-COVID-19 cases, respectively (ns). Both COVID-19 and non-COVID-19 cases had a wide range of neuropathological diagnoses, consistent with their age and derivation from BSHRI, a research center devoted to the study of aging and neurodegenerative disease.

Figures 1 and 2 show photomicrographs and quantification results, respectively, for OMP-1, TH and SNAP25 immunoreactivity in COVID-19 and non-COVID-19 control cases. As expected from previous reports, positive OMP-1 staining was restricted to the peripheral nerve fiber and glomerular cell layers while $\mathrm{TH}$ and especially SNAP-25 were more diffusely distributed throughout the bulb. The area occupied by OMP-1 immunoreactivity in COVID-19 cases was significantly less, about $60 \%$ of that in control cases; $t(43)=-2.908$; $\mathrm{p}=0.006$ (Figure 2a). Analysis of variance showed an overall difference in OMP-1 immunoreactivity between the groups when controls were subdivided by the presence or absence of non-COVID-19 pneumonia; $F(2,42)$ $=4.176 ; p=0.022$ (Figure 2a). Pairwise post hoc significance testing showed significant differences between the COVID-19 group and the controls without pneumonia $(p=0.048)$ but no differences between the COVID19 group and the controls with pneumonia. There was no statistical difference between controls with and without pneumonia.

Analysis of variance showed no significant group differences for TH (Figure 2b) while for SNAP-25 (Figure 2c) the group difference was significant; $F(2,38)=3.878 ; p=0.029$. Significantly less SNAP-25 staining was 
medRxiv preprint doi: https://doi.org/10.1101/2021.12.21.21268119; this version posted December 23, 2021. The copyright holder for this

preprint (which was not certified by peer review) is the author/funder, who has granted medRxiv a license to display the preprint in perpetuity.

It is made available under a CC-BY-NC-ND 4.0 International license .

present in controls with pneumonia as compared to controls without pneumonia $(p=0.025)$ but there were no significant differences between COVID-19 cases and all controls, or between COVID-19 cases and controls subdivided by presence or absence of pneumonia.

As COVID-19 cases differed with respect to the presence or absence of olfactory bulb SARS-CoV-2 RNA, as detected by RT-PCR, we compared immunoreactivity for the 3 antibodies in the PCR-positive and PCRnegative cases versus all controls. For OMP-1, analysis of variance showed a significant difference between groups; $F(2,42)=4.251 ; p=0.02$. Post hoc significance testing showed a significant difference between OBTPCR-negative COVID-19 cases and controls $(p=0.027)$ but no significant difference between COVID-19 OBTPCR-positive and PCR-negative cases. Analysis of variance of the same groups for TH or SNAP-25 staining showed no significant group differences $(p=0.239$ and 0.714 , respectively).

Comparing COVID-19 cases and controls for the presence or absence of a major, neuropathologicallydiagnosed neurodegenerative or cerebrovascular disease, analysis of variance showed no significant difference between groups, with any of the 3 antibodies.

\section{DISCUSSION}

COVID-19 is primarily a respiratory disease but with up to $36 \%$ of patients showing neurological effects ${ }^{1-10}$, there is enormous potential for this additional morbidity and so it is of high importance that the mechanisms of CNS impairment be understood. At present the relative contributions of direct viral brain invasion versus indirect factors are unclear. The most unequivocal direct viral manifestation is acute encephalitis, with a reported mortality rate of $13 \%$, but this has been estimated to occur in only $0.2 \%$ of all cases ${ }^{72}$; furthermore, this is likely an overestimate as virtually all diagnoses have been made radiologically and could not have distinguished between autoimmune mechanisms versus direct viral brain infection. Systemic accompaniments of critical illness, including coagulopathy, aberrant immune responses, hypoxia and multi-organ failure are therefore more likely to account for most of the reported COVID-19-associated neurological syndromes ${ }^{11}$.

Postmortem brain tissue studies support this likelihood, with more than 20 published studies ${ }^{11-31}$ using RTPCR in general agreement that SARS-CoV-2 brain invasion occurs in only a smaller fraction of subjects, and in these the viral copy numbers are often low ${ }^{13,31-35}$. In our own comprehensive brain mapping of SARS-CoV-2 
RNA in 320 brain regions of 20 deceased COVID-19 subjects, the olfactory bulb has been found to be the single most-involved area ${ }^{46,47}$ but still was positive in only 8 of 20 cases. More than 5,000 gene expression changes were present in the olfactory bulb in COVID-19 cases as compared to control autopsies, but there were no differences between COVID-19 cases with positive versus negative RT-PCR results ${ }^{47}$. Fewer gene expression changes, but still more than 1,000 , were found in the amygdala, a main projection target of the olfactory bulb, despite only $2 / 20$ cases being RT-PCR positive there. Pathway analysis for the amygdala indicated enrichment and downregulation, respectively, of immune signaling and neuronal/synaptic networks while in olfactory bulb the top upregulated pathway was related to olfactory signaling.

As SARS-CoV-2 invariably infects the nasopharyngeal mucosa and associated olfactory epithelium 27,31,36,39-45, frequently resulting in hyposmia ${ }^{36-38}$, we hypothesized that a large fraction of COVID-19-related olfactory bulb transcriptional changes may be due to its deafferentation during COVID-19, as spontaneous discharge of olfactory epithelial afferents is a dominant regulator of olfactory bulb neurophysiological activity and connectivity ${ }^{48-50}$.

In this study we report that the olfactory marker protein (OMP-1), a specific marker of olfactory epithelial afferents to the olfactory bulb ${ }^{51-53}$, is significantly depleted in the olfactory bulb of subjects dying with COVID19. This parallels what has been reported in animal model lesions of olfactory epithelium ${ }^{48,54-57}$. Unlike in some animal models ${ }^{54,55,58}$, we did not find that olfactory bulb tyrosine hydroxylase is significantly depleted in the COVID-19 subjects, but this may be dependent on the time elapsed from deafferentation. There was no depletion of SNAP-25, a protein found in most or all neuronal synapses, supporting a selective effect of COVID-19 on olfactory epithelial axons. Neither gene expression changes or OMP-1 immunoreactivity were significantly different in COVID-19 olfactory bulbs with or without positive RT-PCR for SARS-CoV2 RNA, reinforcing an emerging recognition that CNS alterations in COVID-19 may, in the majority of subjects, occur independently of direct viral action.

We suggest that at least some of the COVID-19-associated transcriptional changes that we have reported for the amygdala may be due to transsynaptic effects initiated by olfactory bulb deafferentation, as the amygdala and other brain regions are directly innervated by the olfactory bulb. Olfactory stimulation activates neurons of the amygdala ${ }^{73}$, while olfactory bulbectomy in mice has been reported to cause piriform cortex 
reactions including activation of interneurons, apoptosis of pyramidal neurons and downregulation of regulatory pathways ${ }^{74-79}$. A UK Biobank imaging study of 401 subjects before and after SARS-CoV-2 infection ${ }^{80}$ found markers of tissue damage were primarily in olfactory-related brain regions including the medial and lateral orbitofrontal cortex, the anterior insula, the anterior cingulate cortex and the amygdala. Metabolic imaging in patients with "long COVID" found hypometabolism in the amygdala, hippocampus, and bilateral rectal and orbital gyri ${ }^{81}$, similarly to the decreased global cerebral glucose utilization reported after olfactory bulbectomy in an animal model ${ }^{82}$. A recent study has reported evidence that SARS-CoV-2 infection of supporting olfactory epithelium sustentacular cells may be the cause of olfactory sensory dysfunction in COVID-19 ${ }^{83}$.

Transsynaptic changes following olfactory deafferentation may have diverse behavioral effects. Olfactory bulbectomy is the basis of a rat model of depression ${ }^{84-86}$ associated with inflammatory and intermediate early gene expression in the amygdala ${ }^{87,88}$, and olfactory bulbectomy has also been associated with memory and cognitive deficits thought to be related to basal forebrain cholinergic effects ${ }^{89-94}$, providing a possible substrate for diverse post-acute COVID-19 neurological sequelae.

In conclusion, we report a significant depletion, in olfactory bulb of subjects dying with COVID-19, of OMP1 , a specific marker of primary olfactory sensory input. This may be a structural correlate of the clinical hyposmia reported for many subjects with COVID-19. Associated transsynaptic effects may result in more widespread changes in interconnected brain regions. Limitations of our study include relatively small subject numbers, especially for subgroups, and inclusion of only COVID-19 subjects with severe illness.

\section{ACKNOWLEDGEMENTS}

This project was supported by a Covid-19 Supplement to a National Institute on Aging grant, (3P30AG01961020S1), submitted in response to a Notice of Special Interest (NOSI) issued by the National Institute on Aging (NOT-AG-20-022), to highlight the urgent need for research on Coronavirus Disease $2019 \ldots$. 
Table 1. Case data. Olf. Bulb SCV2 $=$ PCR-+ for SARS-CoV-2 in olfactory bulb; Aclnf $=$ Acute or subacute infarction or ischemic-hypoxic histological changes; $A D=$ Alzheimer's disease; $A$ Dinsuff = $A D$ changes insufficient for diagnosis; $D L B$ = dementia with Lewy bodies; FTLD-TDP = frontotemporal lobar degeneration with TDP-43 proteinopathy; HS = hippocampal sclerosis; LATE = Limbic age-related TDP-43 proteinopathy; LBinsuff = Lewy body disease insufficient for diagnosis of PD or DLB; PD = Parkinson's disease; PART = primary age-related tauopathy; PSP = microscopic changes consistent with progressive supranuclear palsy; $\mathrm{VaD}=$ vascular dementia. For all subjects, exact age is not specified due to privacy regulations. $\mathrm{N} / \mathrm{A}=$ not available or not done. Yellow = Major neuropathological diagnosis.

\begin{tabular}{|c|c|c|c|c|c|c|}
\hline Case & Age & Sex & $\begin{array}{c}\text { COVID- } \\
19\end{array}$ & $\begin{array}{l}\text { Olf. Bulb } \\
\text { SCV2 }\end{array}$ & $\begin{array}{c}\text { Non-COVID- } \\
19 \\
\text { Pneumonia }\end{array}$ & $\begin{array}{c}\text { Neuropathologically-Diagnosed } \\
\text { Conditions }\end{array}$ \\
\hline B1 & 90s & $\mathrm{M}$ & + & - & - & AD; VaD; HS; PSP; TDP-43 (LATE) \\
\hline B2 & $70 \mathrm{~s}$ & $\mathrm{~F}$ & + & - & - & PD; AD; DBS \\
\hline B3 & $70 \mathrm{~s}$ & $\mathrm{M}$ & + & - & - & PART; AcInf \\
\hline B4 & $80 \mathrm{~s}$ & $\mathrm{M}$ & + & + & - & ADinsuff \\
\hline B5 & $90 s$ & $\mathrm{M}$ & + & + & - & ADinsuff \\
\hline B6 & $70 \mathrm{~s}$ & $\mathrm{M}$ & + & - & - & AD; TDP-43 (LATE) \\
\hline B7 & $70 \mathrm{~s}$ & $\mathrm{~F}$ & + & + & - & ADinsuff \\
\hline B8 & $80 \mathrm{~s}$ & $\mathrm{M}$ & + & - & - & AD; MSA; TDP-43 (LATE); Aclnf \\
\hline B9 & $70 \mathrm{~s}$ & $\mathrm{M}$ & + & + & - & AD insuff \\
\hline B10 & $60 s$ & $\mathrm{~F}$ & + & - & - & PART \\
\hline B11 & $90 s$ & $\mathrm{~F}$ & + & - & - & AD; DLB \\
\hline B12 & $80 s$ & $\mathrm{~F}$ & + & + & - & AD; TDP-43 (LATE) \\
\hline B13 & $90 s$ & $\mathrm{M}$ & + & - & - & PSP; ADinsuff \\
\hline B14 & $80 s$ & $\mathrm{~F}$ & + & - & - & $\mathrm{VaD}$ \\
\hline B15 & $90 s$ & $\mathrm{M}$ & + & - & - & AD; DLB \\
\hline B16 & $90 s$ & $\mathrm{M}$ & + & - & - & AD; TDP-43 (LATE) \\
\hline B17 & $80 s$ & $\mathrm{~F}$ & + & - & - & AD; TDP-43 (LATE) \\
\hline B18 & $70 s$ & $\mathrm{M}$ & + & - & - & PART \\
\hline C1 & $70 s$ & $\mathrm{M}$ & - & $\mathrm{N} / \mathrm{A}$ & - & PART \\
\hline C2 & $70 \mathrm{~s}$ & $\mathrm{~F}$ & - & $\mathrm{N} / \mathrm{A}$ & - & ADinsuff \\
\hline C3 & $90 s$ & $M$ & - & $\mathrm{N} / \mathrm{A}$ & + & AD-insuff; LBinsuff \\
\hline C4 & $80 s$ & $\mathrm{~F}$ & - & $\mathrm{N} / \mathrm{A}$ & - & AD-insuff; TDP-43 (LATE) \\
\hline C5 & 90s & $\mathrm{F}$ & - & $\mathrm{N} / \mathrm{A}$ & - & AD-insuff; LATE \\
\hline C6 & $100 \mathrm{~s}$ & $M$ & - & $\mathrm{N} / \mathrm{A}$ & + & PART; LATE \\
\hline C7 & $70 \mathrm{~s}$ & $\mathrm{~F}$ & - & $\mathrm{N} / \mathrm{A}$ & - & ADinsuff \\
\hline $\mathrm{C8}$ & $80 s$ & $\mathrm{M}$ & - & $\mathrm{N} / \mathrm{A}$ & + & AD; Aclnf \\
\hline C9 & $70 \mathrm{~s}$ & $M$ & - & $\mathrm{N} / \mathrm{A}$ & + & PART; AcInf \\
\hline C10 & $70 \mathrm{~s}$ & $M$ & - & N/A & + & AD; PD \\
\hline C11 & $70 s$ & $\mathrm{M}$ & - & $\mathrm{N} / \mathrm{A}$ & + & AD; PD \\
\hline $\mathrm{C} 12$ & $80 s$ & $\mathrm{~F}$ & - & $\mathrm{N} / \mathrm{A}$ & - & AD; VaD; LBinsuff \\
\hline C13 & $80 s$ & $\mathrm{M}$ & - & $\mathrm{N} / \mathrm{A}$ & + & AD; TDP-43 (LATE); LBinsuff \\
\hline C14 & $80 s$ & $\mathrm{M}$ & - & $\mathrm{N} / \mathrm{A}$ & + & PD; PART; TDP-43 (LATE) \\
\hline C15 & $90 s$ & $\mathrm{M}$ & - & $\mathrm{N} / \mathrm{A}$ & - & AD; VaD; ACInf; TDP-43 (LATE) \\
\hline C16 & $90 s$ & $\mathrm{~F}$ & - & $\mathrm{N} / \mathrm{A}$ & - & AD; TDP-43 (LATE) \\
\hline C17 & $90 s$ & $\mathrm{~F}$ & - & $\mathrm{N} / \mathrm{A}$ & - & AD; PSP; HS; FTLD-TDP; VaD \\
\hline C18 & $80 s$ & $\mathrm{M}$ & - & $\mathrm{N} / \mathrm{A}$ & + & AD; DLB; VaD; PSP; TDP-43 (LATE) \\
\hline C19 & $90 s$ & $\mathrm{M}$ & - & $\mathrm{N} / \mathrm{A}$ & - & ADinsuff; LBinsuff; AcInf \\
\hline C2O & $90 s$ & $\mathrm{~F}$ & - & $\mathrm{N} / \mathrm{A}$ & + & AD; TDP-43 (LATE) \\
\hline C21 & $90 s$ & $\mathrm{M}$ & - & $\mathrm{N} / \mathrm{A}$ & + & ADinsuff; TDP-43 (LATE); Aclnf \\
\hline C22 & $90 s$ & $\mathrm{~F}$ & - & $\mathrm{N} / \mathrm{A}$ & + & $\mathrm{AD}$ \\
\hline C23 & $90 s$ & $\mathrm{M}$ & - & $\mathrm{N} / \mathrm{A}$ & + & AD; LBinsuff; TDP-43 (LATE); PSP \\
\hline C24 & $100 \mathrm{~s}$ & $\mathrm{~F}$ & - & $\mathrm{N} / \mathrm{A}$ & + & VaD; TDP-43 (LATE) \\
\hline $\mathrm{C25}$ & $80 \mathrm{~s}$ & $\mathrm{M}$ & - & $\mathrm{N} / \mathrm{A}$ & + & AD; FTLD-TDP; HS; PSP; LBinsuff \\
\hline C26 & $70 s$ & $\mathrm{M}$ & - & $\mathrm{N} / \mathrm{A}$ & - & PART \\
\hline C27 & $80 s$ & $\mathrm{M}$ & - & $\mathrm{N} / \mathrm{A}$ & - & MSA; ADinsuff \\
\hline C28 & $80 s$ & $\mathrm{M}$ & - & $\mathrm{N} / \mathrm{A}$ & - & ADinsuff; TDP-43 (LATE) \\
\hline
\end{tabular}


medRxiv preprint doi: https://doi.org/10.1101/2021.12.21.21268119; this version posted December 23, 2021. The copyright holder for this preprint (which was not certified by peer review) is the author/funder, who has granted medRxiv a license to display the preprint in perpetuity.

It is made available under a CC-BY-NC-ND 4.0 International license .

Figure 1: Photomicrographs representative of OMP-1, TH and SNAP-25 immunoreactivity in a) non-COVID-19 control cases and b) in COVID-19 cases at low and high magnifications, in sections of olfactory bulb. The second row for each set shows the magnification used for image analysis. Immunoreactivity for OMP-1 (dark purple) consists solely of fibers and puncta, consistent with axons and presynaptic terminals, and is restricted to the nerve fiber layer and glomerular layer, as expected from the known termination of nasopharyngeal olfactory sensory afferents. Staining for TH and particularly SNAP-25 (both are dark purple) is distributed more widely. Neuronal cell bodies and dendrites are apparent in the TH-stained sections while only fibers and puncta, consistent with axons, dendrites and synaptic terminals, are seen in the SNAP-25-stained sections.

a)
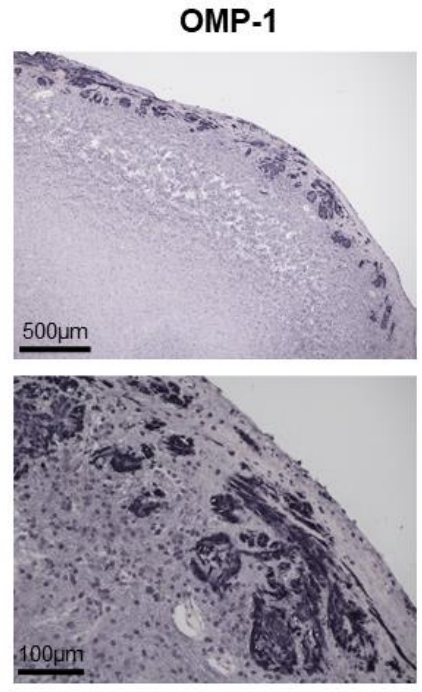

b)
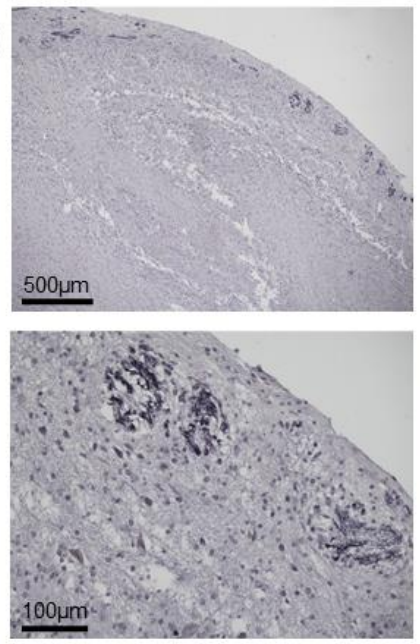

Tyrosine hydroxylase
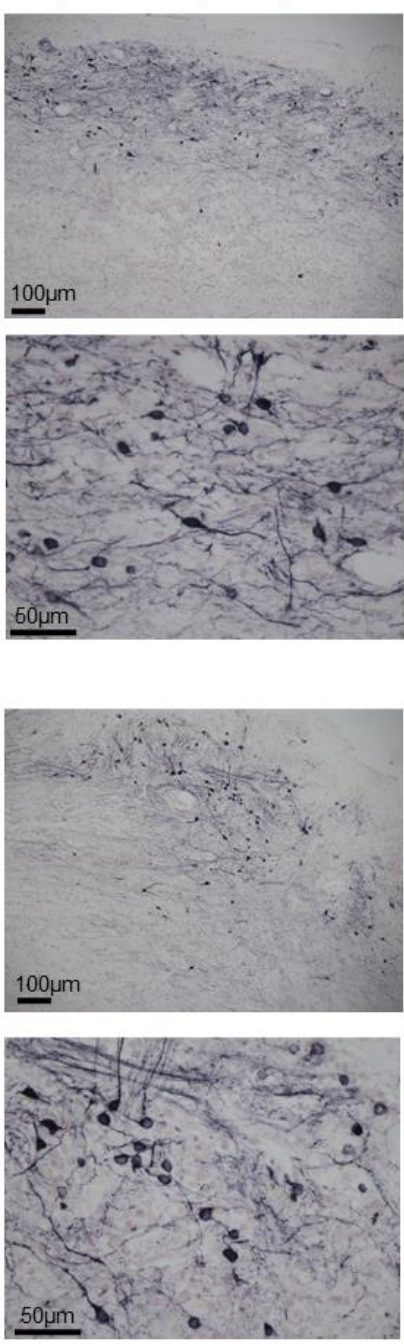

SNAP 25
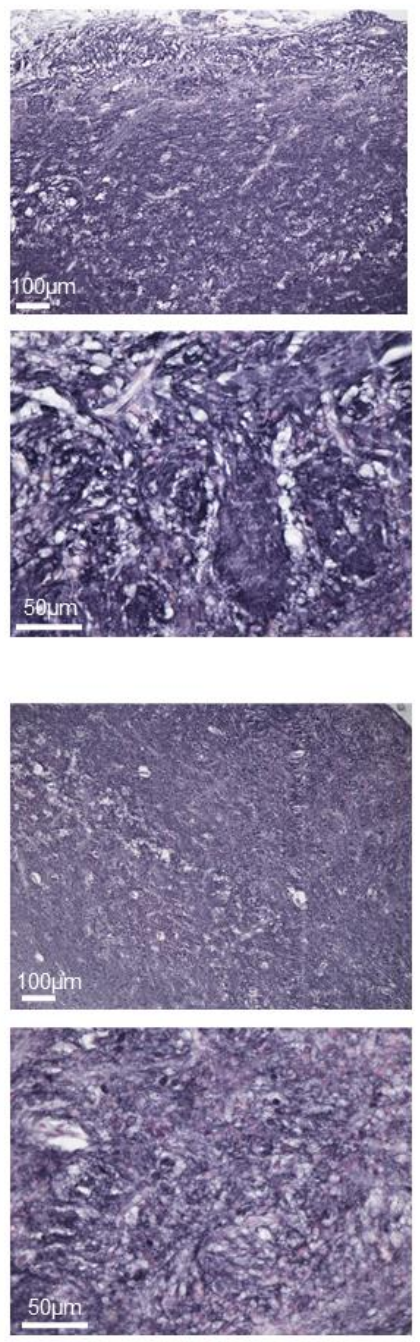
medRxiv preprint doi: https://doi.org/10.1101/2021.12.21.21268119; this version posted December 23, 2021. The copyright holder for this preprint (which was not certified by peer review) is the author/funder, who has granted medRxiv a license to display the preprint in perpetuity.

It is made available under a CC-BY-NC-ND 4.0 International license .

Figure 2: Quantification results for OMP-1, TH and SNAP-25 immunoreactivity for each group. All controls include both controls with and without pneumonia. Means and standard deviations of the means are represented. ${ }^{*}=p<0.05$ (see text for precise $p$ values).

a)

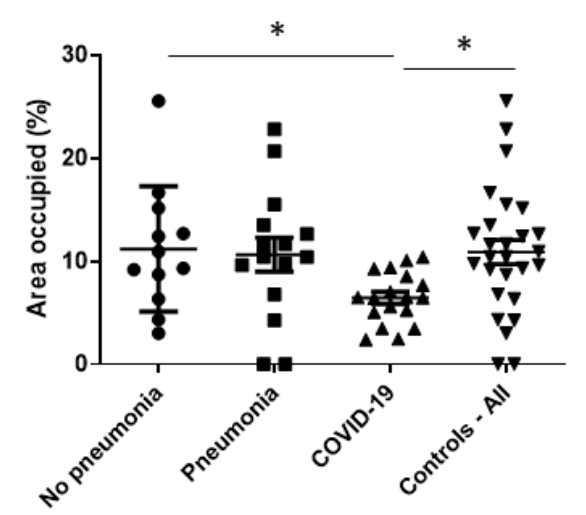

b)

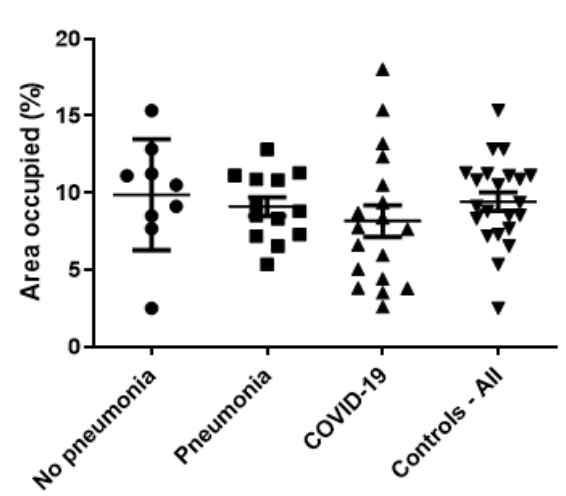

c)

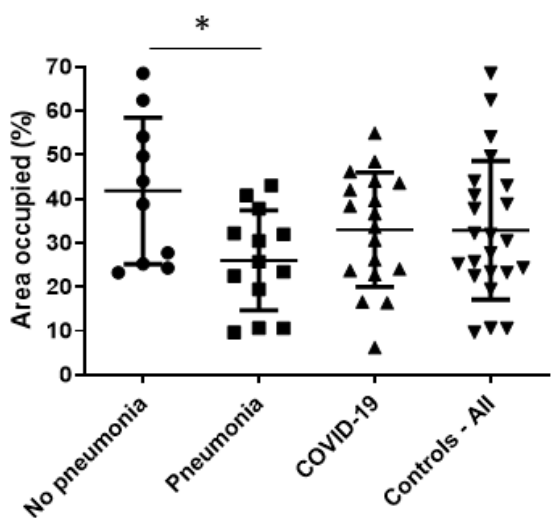


medRxiv preprint doi: https://doi.org/10.1101/2021.12.21.21268119; this version posted December 23, 2021. The copyright holder for this preprint (which was not certified by peer review) is the author/funder, who has granted medRxiv a license to display the preprint in perpetuity. It is made available under a CC-BY-NC-ND 4.0 International license .

\section{REFERENCES}

1. Yassin, A, Nawaiseh, M, Shaban, A, et al. Neurological manifestations and complications of coronavirus disease 2019 (COVID-19): a systematic review and meta-analysis. BMC Neurol. $2021 ; 21: 138$.

2. Varatharaj, A, Thomas, N, Ellul, MA, et al. Neurological and neuropsychiatric complications of COVID19 in 153 patients: a UK-wide surveillance study. Lancet Psychiatry. 2020; 7:875-882.

3. Delamarre, L, Gollion, C, Grouteau, G, et al. COVID-19-associated acute necrotising encephalopathy successfully treated with steroids and polyvalent immunoglobulin with unusual IgG targeting the cerebral fibre network. J Neurol Neurosurg Psychiatry. 2020; 91:1004-1006.

4. Ghannam, M, Alshaer, Q, Al-Chalabi, M, et al. Neurological involvement of coronavirus disease 2019: a systematic review. J Neurol. 2020; 267:3135-3153.

5. Anand, PZLBNHDHGDMC-AAM. Neurologic Findings Among Inpatients with COVID-19 at a Safety-Net U.S. Hospital. Neurology Clin Practice. 2020; In press.

6. Kremer, S, Lersy, F, de, SJ, et al. Brain MRI Findings in Severe COVID-19: A Retrospective Observational Study. Radiology. 2020; 297:E242-E251.

7. Pons-Escoda, A, Naval-Baudin, P, Majos, C, et al. Neurologic Involvement in COVID-19: Cause or Coincidence? A Neuroimaging Perspective. AJNR Am J Neuroradiol. 2020; 41:1365-1369.

8. Romero-Sanchez, CM, Diaz-Maroto, I, Fernandez-Diaz, E, et al. Neurologic manifestations in hospitalized patients with COVID-19: The ALBACOVID registry. Neurology. 2020; 95:e1060e1070.

9. Ellul, MA, Benjamin, L, Singh, B, et al. Neurological associations of COVID-19. Lancet Neurol. 2020; 19:767-783. 
10. Guerrero, JI, Barragan, LA, Martinez, JD, et al. Central and peripheral nervous system involvement by COVID-19: a systematic review of the pathophysiology, clinical manifestations, neuropathology, neuroimaging, electrophysiology, and cerebrospinal fluid findings. BMC Infect Dis. 2021; $21: 515$

11. Deigendesch, N, Sironi, L, Kutza, M, et al. Correlates of critical illness-related encephalopathy predominate postmortem COVID-19 neuropathology. Acta Neuropathol. 2020; 140:583-586.

12. Thakur, KT, Miller, EH, Glendinning, MD, et al. COVID-19 neuropathology at Columbia University Irving Medical Center/New York Presbyterian Hospital. Brain. 2021.

13. Bhatnagar, J, Gary, J, Reagan-Steiner, S, et al. Evidence of Severe Acute Respiratory Syndrome Coronavirus 2 Replication and Tropism in the Lungs, Airways, and Vascular Endothelium of Patients With Fatal Coronavirus Disease 2019: An Autopsy Case Series. J Infect Dis. 2021; 223:752-764.

14. Roden, AC, Vrana, JA, Koepplin, JW, et al. Comparison of In Situ Hybridization, Immunohistochemistry, and Reverse Transcription-Droplet Digital Polymerase Chain Reaction for Severe Acute Respiratory Syndrome Coronavirus 2 (SARS-CoV-2) Testing in Tissue. Arch Pathol Lab Med. 2021; 145:785-796.

15. Sablone, S, Solarino, B, Ferorelli, D, et al. Post-mortem persistence of SARS-CoV-2: a preliminary study. Forensic Sci Med Pathol. 2021.

16. Skok, K, Stelzl, E, Trauner, M, et al. Post-mortem viral dynamics and tropism in COVID-19 patients in correlation with organ damage. Virchows Arch. 2020.

17. Deinhardt-Emmer, S, Wittschieber, D, Sanft, J, et al. Early postmortem mapping of SARS-CoV-2 RNA in patients with COVID-19 and correlation to tissue damage. bioRxiv. 2020;2020. 
medRxiv preprint doi: https://doi.org/10.1101/2021.12.21.21268119; this version posted December 23, 2021. The copyright holder for this preprint (which was not certified by peer review) is the author/funder, who has granted medRxiv a license to display the preprint in perpetuity.

It is made available under a CC-BY-NC-ND 4.0 International license .

18. Bihlmaier, K, Coras, R, Willam, C, et al. Disseminated Multifocal Intracerebral Bleeding Events in Three Coronavirus Disease 2019 Patients on Extracorporeal Membrane Oxygenation As Rescue Therapy. Crit Care Explor. 2020; 2:e0218.

19. Freij, BJ, Gebara, BM, Tariq, R, et al. Fatal central nervous system co-infection with SARS-CoV-2 and tuberculosis in a healthy child. BMC Pediatr. 2020; 20:429.

20. Matschke, J, Lutgehetmann, M, Hagel, C, et al. Neuropathology of patients with COVID-19 in Germany: a post-mortem case series. Lancet Neurol. 2020; 19:919-929.

21. Wichmann, D, Sperhake, JP, Lutgehetmann, M, et al. Autopsy Findings and Venous Thromboembolism in Patients With COVID-19: A Prospective Cohort Study. Ann Intern Med. $2020 ; 173: 268-277$.

22. Paniz-Mondolfi, A, Bryce, C, Grimes, Z, et al. Central nervous system involvement by severe acute respiratory syndrome coronavirus-2 (SARS-CoV-2). J Med Virol. 2020; 92:699-702.

23. Menter, T, Haslbauer, JD, Nienhold, R, et al. Postmortem examination of COVID-19 patients reveals diffuse alveolar damage with severe capillary congestion and variegated findings in lungs and other organs suggesting vascular dysfunction. Histopathology. 2020; 77:198-209.

24. Al-Sarraj, S, Troakes, C, Hanley, B, et al. Invited Review: The spectrum of neuropathology in COVID19. Neuropathol Appl Neurobiol. 2020.

25. Jensen, MP, Le, QJ, Officer-Jones, L, et al. Neuropathological findings in two patients with fatal COVID-19. Neuropathol Appl Neurobiol. 2020.

26. Kantonen, J, Mahzabin, S, Mayranpaa, MI, et al. Neuropathologic features of four autopsied COVID-19 patients. Brain Pathol. 2020; 30:1012-1016.

27. Meinhardt, J, Radke, J, Dittmayer, C, et al. Olfactory transmucosal SARS-CoV-2 invasion as a port of central nervous system entry in individuals with COVID-19. Nat Neurosci. 2020. 
medRxiv preprint doi: https://doi.org/10.1101/2021.12.21.21268119; this version posted December 23, 2021. The copyright holder for this preprint (which was not certified by peer review) is the author/funder, who has granted medRxiv a license to display the preprint in perpetuity. It is made available under a CC-BY-NC-ND 4.0 International license .

28. Puelles, VG, Lutgehetmann, M, Lindenmeyer, MT, et al. Multiorgan and Renal Tropism of SARS-CoV2. N Engl J Med. 2020; 383:590-592.

29. Remmelink, M, De, MR, D'Haene, N, et al. Unspecific post-mortem findings despite multiorgan viral spread in COVID-19 patients. Crit Care. 2020; 24:495.

30. Solomon, IH, Normandin, E, Bhattacharyya, S, et al. Neuropathological Features of Covid-19. N Engl J Med. 2020; 383:989-992.

31. Lopez, G, Tonello, C, Osipova, G, et al. Olfactory bulb SARS-CoV-2 infection is not paralleled by the presence of virus in other central nervous system areas. Neuropathol Appl Neurobiol. 2021.

32. Hur, KH, Park, K, Lim, Y, et al. Evaluation of Four Commercial Kits for SARS-CoV-2 Real-Time Reverse-Transcription Polymerase Chain Reaction Approved by Emergency-Use-Authorization in Korea. Front Med (Lausanne ). 2020; 7:521.

33. Barra, GB, Santa Rita, TH, Mesquita, PG, et al. Analytical Sensitivity and Specificity of Two RT-qPCR Protocols for SARS-CoV-2 Detection Performed in an Automated Workflow. Genes (Basel ). $2020 ; 11$.

34. Wolfel, R, Corman, VM, Guggemos, W, et al. Virological assessment of hospitalized patients with COVID-2019. Nature. 2020; 581:465-469.

35. El Jamal, SM, Pujadas, E, Ramos, I, et al. Tissue-based SARS-CoV-2 detection in fatal COVID-19 infections: Sustained direct viral-induced damage is not necessary to drive disease progression. Hum Pathol. 2021; 114:110-119.

36. Bhatta, S, Sharma, D, Sharma, S, et al. Smell and Taste Disturbance in COVID-19 Patients: A Prospective Multicenteric Review. Indian J Otolaryngol Head Neck Surg. 2021;1-7. 
medRxiv preprint doi: https://doi.org/10.1101/2021.12.21.21268119; this version posted December 23, 2021. The copyright holder for this preprint (which was not certified by peer review) is the author/funder, who has granted medRxiv a license to display the preprint in perpetuity.

It is made available under a CC-BY-NC-ND 4.0 International license .

37. Levinson, R, Elbaz, M, Ben-Ami, R, et al. Anosmia and dysgeusia appeared early in third of our patients with mild SARS-CoV-2 infection and were short-lived in most patients. MEDRXIV. 2020; https://doi.org/10.1101/2020.04.11.20055483.

38. Eliezer, M, Hautefort, C, Hamel, AL, et al. Sudden and Complete Olfactory Loss Function as a Possible Symptom of COVID-19. JAMA Otolaryngol Head Neck Surg. 2020.

39. Jiao, L, Yang, Y, Yu, W, et al. The olfactory route is a potential way for SARS-CoV-2 to invade the central nervous system of rhesus monkeys. Signal Transduct Target Ther. 2021; 6:169.

40. Ye, Q, Zhou, J, He, Q, et al. SARS-CoV-2 infection in the mouse olfactory system. Cell Discov. 2021; $7: 49$.

41. Monchatre-Leroy, E, Lesellier, S, Wasniewski, M, et al. Hamster and ferret experimental infection with intranasal low dose of a single strain of SARS-CoV-2. J Gen Virol. 2021; 102.

42. de Melo, GD, Lazarini, F, Levallois, S, et al. COVID-19-related anosmia is associated with viral persistence and inflammation in human olfactory epithelium and brain infection in hamsters. Sci TransI Med. 2021; 13.

43. Lima, M, Siokas, V, Aloizou, AM, et al. Unraveling the Possible Routes of SARS-COV-2 Invasion into the Central Nervous System. Curr Treat Options Neurol. 2020; 22:37.

44. Xydakis, MS, Albers, MW, Holbrook, EH, et al. Post-viral effects of COVID-19 in the olfactory system and their implications. Lancet Neurol. 2021; 20:753-761.

45. Zhang, AJ, Lee, AC, Chu, H, et al. Severe Acute Respiratory Syndrome Coronavirus 2 Infects and Damages the Mature and Immature Olfactory Sensory Neurons of Hamsters. Clin Infect Dis. 2021; 73:e503-e512.

46. Serrano, GE, Walker, JE, Arce, R, et al. Mapping of SARS-CoV-2 Brain Invasion and Histopathology in COVID-19 Disease. medRxiv. 2021. 
medRxiv preprint doi: https://doi.org/10.1101/2021.12.21.21268119; this version posted December 23, 2021. The copyright holder for this preprint (which was not certified by peer review) is the author/funder, who has granted medRxiv a license to display the preprint in perpetuity. It is made available under a CC-BY-NC-ND 4.0 International license .

47. Piras, IS, Huentelman, MJ, Walker, JE, et al. Olfactory Bulb and Amygdala Gene Expression Changes in Subjects Dying with COVID-19. medRxiv. 2021.

48. Buiakova, OI, Baker, H, Scott, JW, et al. Olfactory marker protein (OMP) gene deletion causes altered physiological activity of olfactory sensory neurons. Proc Natl Acad Sci U S A. 1996; 93:98589863.

49. Lorenzon, P, Redolfi, N, Podolsky, MJ, et al. Circuit formation and function in the olfactory bulb of mice with reduced spontaneous afferent activity. J Neurosci. 2015; 35:146-160.

50. Redolfi, N and Lodovichi, C. Spontaneous Afferent Activity Carves Olfactory Circuits. Front Cell Neurosci. 2021; 15:637536.

51. Margolis, FL. Olfactory marker protein (OMP). Scand J Immunol Suppl. 1982; 9:181-199.

52. Monti-Graziadei, GA, Margolis, FL, Harding, JW, et al. Immunocytochemistry of the olfactory marker protein. J Histochem Cytochem. 1977; 25:1311-1316.

53. Wensley, $\mathrm{CH}$, Stone, DM, Baker, $\mathrm{H}$, et al. Olfactory marker protein mRNA is found in axons of olfactory receptor neurons. J Neurosci. 1995; 15:4827-4837.

54. Biffo, S, DeLucia, R, Mulatero, B, et al. Carnosine-, calcitonin gene-related peptide- and tyrosine hydroxylase-immunoreactivity in the mouse olfactory bulb following peripheral denervation. Brain Res. 1990; 528:353-357.

55. Byrd, CA. Deafferentation-induced changes in the olfactory bulb of adult zebrafish. Brain Res. 2000; 866:92-100.

56. Cummings, DM, Emge, DK, Small, SL, et al. Pattern of olfactory bulb innervation returns after recovery from reversible peripheral deafferentation. J Comp Neurol. 2000; 421:362-373. 
medRxiv preprint doi: https://doi.org/10.1101/2021.12.21.21268119; this version posted December 23, 2021. The copyright holder for this preprint (which was not certified by peer review) is the author/funder, who has granted medRxiv a license to display the preprint in perpetuity.

It is made available under a CC-BY-NC-ND 4.0 International license .

57. Verhaagen, J, Oestreicher, AB, Grillo, M, et al. Neuroplasticity in the olfactory system: differential effects of central and peripheral lesions of the primary olfactory pathway on the expression of B50/GAP43 and the olfactory marker protein. J Neurosci Res. 1990; 26:31-44.

58. Paskin, TR, Iqbal, TR, and Byrd-Jacobs, CA. Olfactory bulb recovery following reversible deafferentation with repeated detergent application in the adult zebrafish. Neuroscience. 2011; 196:276-284.

59. Nelson, PT, Dickson, DW, Trojanowski, JQ, et al. Limbic-predominant age-related TDP-43 encephalopathy (LATE): consensus working group report. Brain. 2019; 142:1503-1527.

60. Dickson, DW, Rademakers, R, and Hutton, ML. Progressive supranuclear palsy: pathology and genetics. Brain Pathol. 2007; 17:74-82.

61. Dickson, DW, Ahmed, Z, Algom, AA, et al. Neuropathology of variants of progressive supranuclear palsy. Curr Opin Neurol. 2010; 23:394-400.

62. Crary, JF, Trojanowski, JQ, Schneider, JA, et al. Primary age-related tauopathy (PART): a common pathology associated with human aging. Acta Neuropathol. 2014; 128:755-766.

63. Kovacs, GG, Ferrer, I, Grinberg, LT, et al. Aging-related tau astrogliopathy (ARTAG): harmonized evaluation strategy. Acta Neuropathol. 2016; 131:87-102.

64. Roman, GC, Tatemichi, TK, Erkinjuntti, T, et al. Vascular dementia: diagnostic criteria for research studies. Report of the NINDS-AIREN International Workshop. Neurology. 1993; 43:250-260.

65. Mackenzie, IR, Neumann, M, Baborie, A, et al. A harmonized classification system for FTLD-TDP pathology. Acta Neuropathol. 2011; 122:111-113.

66. Gelb, DJ, Oliver, E, and Gilman, S. Diagnostic criteria for Parkinson disease. Arch Neurol. 1999; 56:3339. 
medRxiv preprint doi: https://doi.org/10.1101/2021.12.21.21268119; this version posted December 23, 2021. The copyright holder for this preprint (which was not certified by peer review) is the author/funder, who has granted medRxiv a license to display the preprint in perpetuity. It is made available under a CC-BY-NC-ND 4.0 International license .

67. Dickson, DW, Braak, H, Duda, JE, et al. Neuropathological assessment of Parkinson's disease: refining the diagnostic criteria. Lancet Neurol. 2009; 8:1150-1157.

68. Dickson, DW. Required techniques and useful molecular markers in the neuropathologic diagnosis of neurodegenerative diseases. Acta Neuropathol. 2005; 109:14-24.

69. Hyman, BT, Phelps, CH, Beach, TG, et al. National Institute on Aging-Alzheimer's Association guidelines for the neuropathologic assessment of Alzheimer's disease. Alzheimers Dement. 2012; 8:1-13.

70. Montine, TJ, Phelps, CH, Beach, TG, et al. National Institute on Aging-Alzheimer's Association guidelines for the neuropathologic assessment of Alzheimer's disease: a practical approach. Acta Neuropathol. 2012; 123:1-11.

71. McKeith, IG, Dickson, DW, Lowe, J, et al. Diagnosis and management of dementia with Lewy bodies: third report of the DLB Consortium. Neurology. 2005; 65:1863-1872.

72. Siow, I, Lee, KS, Zhang, JJY, et al. Encephalitis as a neurological complication of COVID-19: A systematic review and meta-analysis of incidence, outcomes, and predictors. Eur J Neurol. $2021 ; 28: 3491-3502$.

73. Kikusui, T, Kajita, M, Otsuka, N, et al. Sex differences in olfactory-induced neural activation of the amygdala. Behav Brain Res. 2018; 346:96-104.

74. Wilson, DA, Best, AR, and Brunjes, PC. Trans-neuronal modification of anterior piriform cortical circuitry in the rat. Brain Res. 2000; 853:317-322.

75. Kim, HH, Puche, AC, and Margolis, FL. Odorant deprivation reversibly modulates transsynaptic changes in the NR2B-mediated CREB pathway in mouse piriform cortex. J Neurosci. 2006; 26:9548-9559. 
medRxiv preprint doi: https://doi.org/10.1101/2021.12.21.21268119; this version posted December 23, 2021. The copyright holder for this preprint (which was not certified by peer review) is the author/funder, who has granted medRxiv a license to display the preprint in perpetuity.

It is made available under a CC-BY-NC-ND 4.0 International license .

76. Koliatsos, VE, Dawson, TM, Kecojevic, A, et al. Cortical interneurons become activated by deafferentation and instruct the apoptosis of pyramidal neurons. Proc Natl Acad Sci U S A. $2004 ; 101: 14264-14269$.

77. Capurso, SA, Calhoun, ME, Sukhov, RR, et al. Deafferentation causes apoptosis in cortical sensory neurons in the adult rat. J Neurosci. 1997; 17:7372-7384.

78. Zhou, L, Welsh, AM, Chen, D, et al. NMDA inhibitors cause apoptosis of pyramidal neurons in mature piriform cortex: evidence for a nitric oxide-mediated effect involving inhibitory interneurons. Neuropharmacology. 2007; 52:1528-1537.

79. Leung, $\mathrm{CH}$ and Wilson, DA. Trans-neuronal regulation of cortical apoptosis in the adult rat olfactory system. Brain Res. 2003; 984:182-188.

80. Douaud, GI, Lee, S, Alfaro-Almagro, F, et al. Brain imaging before and after COVID-19 in UK Biobank. medRxiv. $2021 ; 2021$.

81. Guedj, E, Campion, JY, Dudouet, P, et al. (18)F-FDG brain PET hypometabolism in patients with long COVID. Eur J Nucl Med Mol Imaging. 2021; 48:2823-2833.

82. Skelin, I, Sato, H, and Diksic, M. Olfactory bulbectomy reduces cerebral glucose utilization: 2[14C]deoxyglucose autoradiographic study. Brain Res Bull. 2008; 76:485-492.

83. Khan, M, Yoo, SJ, Clijsters, M, et al. Visualizing in deceased COVID-19 patients how SARS-CoV-2 attacks the respiratory and olfactory mucosae but spares the olfactory bulb. Cell. 2021; 184:5932-5949.

84. Kelly, JP, Wrynn, AS, and Leonard, BE. The olfactory bulbectomized rat as a model of depression: an update. Pharmacol Ther. 1997; 74:299-316.

85. Leonard, BE. The olfactory bulbectomized rat as a model of depression. Pol J Pharmacol Pharm. 1984; $36: 561-569$. 
medRxiv preprint doi: https://doi.org/10.1101/2021.12.21.21268119; this version posted December 23, 2021. The copyright holder for this preprint (which was not certified by peer review) is the author/funder, who has granted medRxiv a license to display the preprint in perpetuity.

It is made available under a CC-BY-NC-ND 4.0 International license .

86. Skelin, I, Kovacevic, T, Sato, H, et al. Upregulated arachidonic acid signalling in the olfactory bulbectomized rat model of depression. Neurochem Int. 2011; 58:483-488.

87. Wrynn, AS, Sebens, JB, Koch, T, et al. Prolonged c-Jun expression in the basolateral amygdala following bulbectomy: possible implications for antidepressant activity and time of onset. Brain Res Mol Brain Res. 2000; 76:7-17.

88. Burke, NN, Geoghegan, E, Kerr, DM, et al. Altered neuropathic pain behaviour in a rat model of depression is associated with changes in inflammatory gene expression in the amygdala. Genes Brain Behav. 2013; 12:705-713.

89. Takahashi, K, Tsuji, M, Nakagawasai, O, et al. Activation of cholinergic system partially rescues olfactory dysfunction-induced learning and memory deficit in mice. Behav Brain Res. 2021; 408:113283.

90. Moriguchi, S, Inagaki, R, and Fukunaga, K. Memantine improves cognitive deficits via KATP channel inhibition in olfactory bulbectomized mice. Mol Cell Neurosci. 2021; 117:103680.

91. Moriguchi, S, Inagaki, R, Shimojo, H, et al. Memantine Improves Depressive-like Behaviors via Kir6.1 Channel Inhibition in Olfactory Bulbectomized Mice. Neuroscience. 2020; 442:264-273.

92. Yabuki, Y, Matsuo, K, Hirano, K, et al. Combined Memantine and Donepezil Treatment Improves Behavioral and Psychological Symptoms of Dementia-Like Behaviors in Olfactory Bulbectomized Mice. Pharmacology. 2017; 99:160-171.

93. Bobkova, N, Vorobyov, V, Medvinskaya, N, et al. Immunization Against Specific Fragments of Neurotrophin p75 Receptor Protects Forebrain Cholinergic Neurons in the Olfactory Bulbectomized Mice. J Alzheimers Dis. 2016; 53:289-301.

94. Vorobyov, V, Medvinskaya, N, Deev, A, et al. Spatial memory deficits initiated by agroclavine injection or olfactory bulbectomy in rats are characterized by different levels of long-term potentiation expression in the hippocampus. Int J Neurosci. 2020; 130:1225-1229. 